\title{
The Gradualist Chapter of the bSam gtan mig sgron and the Teaching of Kamalaśíla
}

\section{Izumi MIYAZAKI}

I have pointed out elsewhere that although the bSam gtan mig sgron ${ }^{1)}(S M G)$, ascribed to gNubs chen Sańs rgyas ye śes, itself insists that the contents of the Gradualist chapter are the teaching of Kamalaśila, the $S M G$ deviates from his teaching at many points. ${ }^{2)}$ But since my earlier article deals only with the section on the two truths (satyadvaya), in this article, I examine the section on "the four immeasurables" and "tranquility and insight" so that we can compare them to the teaching of Kamalaśîla.

The four immeasurables (caturapramāna) are loving kindness (maitrī), compassion (karunāa), joy (muditā), and indifference (upekșā). In the Gradualist chapter of the $S M G$, the meditation on the four immeasurables is explained in the first of the sections on meditation, namely before the section on the two truths. Here we examine how and in which order they are explained, with reference to the teaching of Kamalaśîla.

First, the $S M G$ [67.5] states in the last part of this section :

We do not describe in detail here, but it is explained in the three Bhāvanākramas.

This apparently means that the $S M G$ follows the Bhāvanākrama (BhK) and explains the four immeasurables by summarizing the contents of the three $B h K$ 's.

But, in fact, none of the BhK's explains all four immeasurables ; only some of them are explained, concerning the practice of compassion before generating the mind of enlightenment (bodhicitta).

The first $B h K$ explains only compassion. The second $B h K$ has a more detailed explanation, in which loving kindness and indifference are also mentioned. Indifference, loving kindness, and compassion are explained in that order, and the first two are preparatory stages to the practice of compassion. In the third $B h K$, the practice of compassion is not described in detail. 
( 54 ) The Gradualist Chapter of the bSam gtan mig sgron and the Teaching of Kamalaśila (I. MIYAZAKI)

We compare the $S M G$ to the second $B h K$, which has the most detailed explanations of loving kindness, compassion and indifference.

The four immeasurables section of the $S M G$ reads as follows : [SMG, 66.5-7.4]

At first, one should practice compassion. If one sees the sentient beings that are non-arising objects at the level of the ultimate truth, one should be tormented exceedingly, saying, "they are suffering. Oh!” -.. After that, [one should practice] loving kindness, which is considering all sentient beings as one's own sons, just as a mother loves her only son. And then one should remove regret by joy. One should not abandon any sentient beings due to indifference.

Unlike the $S M G$, the second $B h K$ describes indifference and loving kindness as the preparatory stages to compassion. The following extracts from the second $B h K$ are in the order in which they appear in the text.

[The second BhK, ed. Goshima, 5.17-7.9. D. 42b7-44a2, P. 46b3-48al]

Now the sequence of the practice of compassion will be described, beginning with the first entering. First, one should complete calming one's mind, removing attachment to and anger against all sentient beings through the practice of indifference. $\cdots$ Then one should practice loving kindness after finishing calming one's mind towards all the sentient beings. If, after having moistened the stream of one's mind with the water of loving kindness and made [the mind stream] just like the ground under which lies gold, one plants the seeds of compassion, they will easily grow very much. Then, after soaking one's mind stream with loving kindness, one should practice compassion.

The first sentence clearly suggests that the practice of indifference and loving kindness are part of the practice of compassion. Furthermore in the second $B h K$, the immeasurables are explained in the order of indifference, loving kindness and compassion; joy is omitted.

Thus, it is very clear that the $S M G$, which contains an explanation of joy and explains compassion first, deviates from the second $B h K$. It is very likely that the author of the $S M G$ did not know that none of the three $B h K$ 's explains all four immeasurables; he only knew that compassion is explained first.

Since the explanations of the other three immeasurables besides compassion in the $S M G$ are very short, it might be dfficult to decide their order from the description in that text. But even if the SMG did not intend to indicate the order of the three, the first explanation of compassion clearly deviates from that of the $B h K$. Moreover, 
the $S M G$ pays no attention to the relations between indifference, loving kindness, and compassion. This can well lead at least to the conclusion that the $S M G$ does not know the $B h K$ in detail.

Now we will look at the differences between the $S M G$ and the $B h K$ 's in the section on tranquility and insight, focussing on one passage, which corresponds fairly closely to the $B h K$. To make a literal comparison, we will cite the Tibetan text. Common expressions are underlined, and portions that do not use the same words but have the same meaning are indicated by a wavy underline.

SMG, 77.3-6. (1) ñes pa'i skyon ni / le lo dan / dmigs pa brjed pa dan / byin rgod dan / mi rtsol ba dan / rtsol ba'o //

(2) de spon pa'i gñen po ni / 'du byed brgyad de / dad pa dan / 'dun pa dan / rtsol ba dan / śin tu sbyañs pa dan் / dran pa dan / śes bźin dan / sems pa dan / btan் sñoms so //

de spyo cas pa'i span tshul ni // (3) dan po bźi le lo’i gñen po'o // (4) dran pa ni dmigs pa brjed pa'i gñen po'o // śes bźin ni byin rgod kyi gñen po’o // (5) de gñis po rtogs nas spañ no // byin rgod dan ldan na mi rtsol ba ñes pa'o // de sems pas span no // byin rgod dan bral pa'i tshe / rtsol ba ñes* pa ste / btan sñoms kyis span no no //

*SMG : rñed.

\section{the first $B h K$, ed. Tucci, 256.18-57.16 (omit)}

Although there are some problems regarding the content itself, we first examine the differences in language. Looking at the underlined and wavy-underlined portions, we can easily see that the same contents are often presented in different words. We can also see that the $S M G$, although it seems to be based on the $B h K$, omits many things.

Specifically, the first sentence of the $S M G$ (1) largely agrees with the $B h K$. The next wavy-underlined sentence (2) about the eight things by which one can remove the faults (spon ba'i'du byed, prahānasamskāra) is remarkable, since it is very strange that although both the $S M G$ and the $B h K$ have the word spon ba, in the $S M G$, spon $b a$ is separated from ' $d u$ byed, and consequently the compound spon ba' $i$ 'du byed cannot be found in the SMG. In (3), the word dan po is changed from gon ma. After the $S M G$ omits a long portion from the $B h K$, the two texts agree briefly before they diverge in wording, although not in content.

There is a problem here regarding the number of faults ( $\tilde{n} e s p a$ ). The $B h K$ clearly states that there are six faults (ñes pa drug), but the $S M G$ seems to enumerate only 
( 56 ) The Gradualist Chapter of the bSam gtan mig sgron and the Teaching of Kamalasila (I. MrYAZAKI)

five, using the compound, byin rgod (layauddhatya), thus putting drowsiness (byin $b a)$ and agitation $(\operatorname{rgod} p a)$ together. The expression in the latter part of the citation, śes bźin ni byin rgod kyi gñen po'o, could lead to the same conclusion.

It is already known that there is a tradition of five faults, for example, in the Madhyāntavibhāga (IV-4) ${ }^{3)}$ as well as a tradition of six faults, as in the BhK. If we could say that the $S M G$ counts only five faults, it would show us that the $S M G$ doesn't know the $B h K$ correctly. At least the $S M G$ is not aware of the enumeration of six faults in the $B h K$.

Due to limitations of space, we cannot look further at the other parts of this section, but it can be seen from the example above that in the section of tranquility and insight, too, the $S M G$ has many different expressions from the $B h K$ and probably contains deviations from the $B h K$.

We have verified that there are problems regarding the statement in the $S M G$ that the contents of the Gradualist chapter of the $S M G$ conform to the teachings of Kamalaśila concerning the section of the four immeasurables and tranquility and insight. Furthermore, we also found many deviations from the $B h K$ in these sections.

Now the question remains, whether such an interpretation of Kamalaśila derives only from misunderstanding on the part of the author of the $S M G$, or whether there was a tradition of such an interpretation. It is difficult to settle this guestion because of the insufficiency of other sources. One thing we can say now is that such an understanding of Kamalaśila really existed in Tibet.

1) rNal 'byor mig gi bsam gtan or bSam gtan mig sgron: A treatise on bhāvanāa and dhyāna and the relationships between the various approaches to Buddhist contemplative practice by gNubs chen Sans rgyas ye śes, Leh, 1974.

2）拙稿「『禅定灯明論』漸門派章について」,『日本西蔵学会々報』48, 2002, pp. 43-50

3）御牧克己「チベット仏教修行の一断面一所謂「チベット牧象図」について一」, 平成 8-11 年度科学研究費補助金研究成果報告書『修行の研究』, 京都, 2000, p. 69. We do not intend to say here that the $S M G$ follows the Madhyāntavibhāga because there are important differences in terminology; namely, the $S M G$ and the BhK use ābhoga and anābhoga for the last two faults, while Madhyāntavibhāga mentions them as samskāra and asamskāra.

〈Key Words〉 bSam gtan mig sgron, tshad med pa bźi, źi gnas, lhag mthon, Kamalaśila

(COE research associate, Kyoto University) 